\title{
KEANEKARAGAMAN MAKROZOOBENTOS DI SUNGAI TALAWAAN MINAHASA UTARA, SULAWESI UTARA
}

\author{
Mentari Maith $^{1)}$, Sendy Rondonuwu ${ }^{1)}$, Adelfia Papu' ${ }^{1)}$, Marina F.O Singkoh ${ }^{1)}$ \\ ${ }^{1)}$ Program Studi Biologi FMIPA Universitas Sam Ratulangi Manado \\ e-mail:_mentarytary161010@yahoo.com; rondonuwu64@yahoo.com; adelfiaura@gmail.com; \\ marinagosal@yahoo.com
}

\begin{abstract}
ABSTRAK
Makrozoobentos merupakan hewan makroinvertebrata yang menetap di dasar perairan baik sesil, merayap maupun menggali lubang. Beberapa alasan menjadikan makrozoobentos sebagai bioindikator adalah makrozoobentos relatif diam di dasar perairan sehingga terdedah oleh air, pendedahan yang terus menerus menyebabkan makrozoobentos dipengaruhi oleh kegiatan lingkungan dan perubahan tersebut dapat mempengaruhi keanekaragamannya. Penelitian ini bertujuan untuk menganalisis keanekaragaman makrozoobentos di Sungai Talawaan. Lokasi penelitian terletak di Sungai Talawaan, Minahasa Utara, Sulawesi Utara. Penelitian ini menggunakan metode Purposive Random Sampling dengan menggunakan alat jaring surber. Total individu yang didapatkan dari 3 stasiun sebanyak 191 individu dengan jumlah ordo sebanyak 6 yang terdiri dari 14 genus. Genus makrozoobentos yang paling banyak ditemukan pada ke 3 stasiun yaitu Ephemeroptera, Tricoptera dan Coleoptera. Nilai total ke 3 Stasiun termasuk pada kelompok tercemar ringan dengan Indeks keanekaragaman > 2,0 yaitu 2,01.
\end{abstract}

Kata Kunci: Makrozoobentos, Sungai Talawaan, Indeks Keanekaragaman, Minahasa UtaraSulawesi Utara.

\section{DIVERSITY MACROZOOBENTHOS IN TALAWAAN RIVER NORTH MINAHASA, NORTH SULAWESI}

\begin{abstract}
Macrozoobenthos is macroinvertebrate animals that live in the waters of both sessile base, edging and dig a hole. Several reasons make macrozoobenthos bioindicator is macrozoobenthos relatively silent in the bottom waters that were exposed by the water, continuous exposure causes macrozoobenthos influenced by environmental activities and these change may affect biodiversity. This study aims to analyze the diversity of macrozoobenthos in the River Talawaan. Location of the study lies in Talawaan River, North Minahasa, North Sulawesi. The study used Purposive Random Sampling method by using a surber net. Total individuals who come from 3 to as many 191 individual station with the order many as 6 which consists of 14 gems. Genus macrozoobenthos most commonly found at all 3 station are Ephemeroptera, Tricoptera and Coleoptera. The total value of all 3 stations included in the group of lightly contaminated with diversity index $>2,0$ is 2,01.
\end{abstract}

Keywords: Macrozoobenthos, River Talawaan, Diversity index, North Minahasa-North Sulawesi.

\section{PENDAHULUAN}

Makrozoobentos memiliki pergerakan relatif lambat serta daur hidup yang relatif lama sehingga mampu merespon kondisi kualitas air secara terus menerus (Zulkifli dan Setiawan, 2011). Keberadaan hewan bentos terdapat di seluruh badan sungai mulai dari hulu hingga ke hilir.
Hewan makroinvertebrata dapat digunakan sebagai indikator biologis adanya pencemaran. (Siahaan, 2012). Perairan yang berkualitas baik biasanya memiliki keanekaragaman jenis yang tinggi dan sebaliknya pada perairan yang buruk atau tercemar memiliki keanekaragaman yang rendah (Fachrul, 2007).

Sungai sering digunakan manusia untuk berbagai keperluan diantaranya sebagai 
tempat untuk membuang hasil sampingan, sehingga secara tidak langsung dapat masuk ke perairan (Polii dan Sonya, 2002). Kecamatan Talawaan, Kabupaten Minahasa Utara masih merupakan wilayah eksplorasi PT. Tambang Tondano Nusajaya (TTN) yang saat ini terdapat kegiatan pertambangan emas rakyat secara ilegal. Kegiatan ilegal di wilayah ini berlangsung sejak tahun 1985 sampai sekarang dan dilakukan oleh masyarakat setempat dan warga pendatang.

Mengingat peran penting makrozoobentos di perairan dan perlu adanya informasi/data tentang keanekaragaman makrozoobentos maka telah dilakukan penelitian melalui serangkaian pengamatan, pengukuran faktor fisika kimia air, menentukan kualitas air Sungai Talawaan, Minahasa Utara, Sulawesi Utara berdasarkan indeks keanekaragaman makrozoobentos

\section{METODOLOGI PENELITIAN Tempat dan Waktu Penelitian}

Penelitian ini dilaksanakan pada bulan juni-juli 2014. Lokasi penelitian yaitu pada Sungai Talawaan, Minahasa Utara, Sulawesi Utara (Gambar 1).

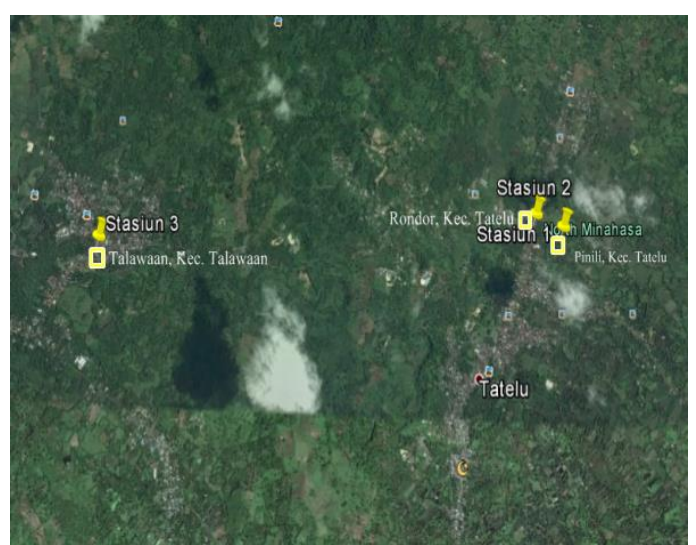

Gambar 1. Lokasi penelitian (Sungai Talawan, Minahasa Utara, SULUT).

\section{Teknik Pengambilan Sampel}

Penelitian ini menggunakan metode Purposive Random Sampling dengan lokasi pengambilan sampel yaitu daerah sebelum perkebunan, pemukiman dan setelah pertambangan. Pengambilan sampel makrozoobentos dengan menggunakan jaring surber.

Makrozoobentos yang didapat kemudian dimasukan kedalam botol yang telah berisi alkohol $70 \%$ sebagai pengawet.
Sampel yang didapatkan dilapangan kemudian diidentifikasi di Laboratorium Ekologi FMIPA UNSRAT dengan menggunakan lup (kaca pembesar) dan mikroskop.

Identifikasi sampel menggunakan Internet, Borror (1992) dan Pemak (1953). Analisis data dilakukan dengan menghitung indeks keanekaragaman, indeks keseragaman dan indeks dominansi.

\section{HASIL DAN PEMBAHASAN}

Lokasi pengambilan sampel pada Stasiun I yaitu pada daerah sebelum perkebunan terdapat di desa Pinili, Kecamatan Tatelu. Pengambilan sampel yang kedua yaitu pada daerah pemukiman (Stasiun II) terdapat di desa Rondor, Kecamatan Tatelu. Pengambilan sampel yang terakhir yaitu pada daerah setelah pertambangan (Stasiun III) terdapat di desa Talawaan, Kecamatan Talawaan, Minahasa Utara.

Total individu yang ditemukan di Sungai Talawaan dari 3 Stasiun yaitu sebanyak 19 individu yang terdiri dari 14 Genus. Banyak genus yang ditemukan pada Stasiun I sebanyak 9 Genus dengan total individu 72. Pada Stasiun II ditemukan 10 genus dengan total individu 39, sedangkan pada Stasiun III ditemukan 6 genus dengan total individu sebanyak 80.

Hasil analisis Indeks Keanekaragaman ( $\left.\mathrm{H}^{\prime}\right)$, Keseragaman (E), dan Dominansi (D) Makrozoobentos di Sungai Talawaan, Minahasa Utara, Sulawesi Utara.

Tabel 1. Total Indeks Keanekaragaman (H'), Keseragaman (E), dan Dominansi (D)

\begin{tabular}{lcccc}
\hline \multicolumn{1}{c}{ Indeks } & \multicolumn{3}{c}{ Stasiun } & \multicolumn{2}{c}{ Sungai Talawaan } \\
\cline { 2 - 4 } & $\mathbf{l}$ & $\mathbf{2}$ & $\mathbf{3}$ & \\
\hline Keanekaragaman H' & 1,99 & 1,95 & 1,38 & 2,01 \\
Keseragaman(E) & 0,91 & 0,85 & 0,77 & 0,77 \\
Dominansi(D) & 0,15 & 0,15 & 0,13 & 0,15 \\
\hline
\end{tabular}

Nilai total Indeks keanekaragaman $\left(\mathrm{H}^{\prime}\right)$ yang didapat dari ke 3 Stasiun di Sungai Talawaan termasuk dalam kelompok tercemar ringan > 2,0 yaitu 2,01 (Tabel 1). Nilai keanekaragaman tertinggi terdapat pada Stasiun I $(1,99)$, Stasiun II $(1,95)$ dan nilai keanekaragaman terendah ditemukan pada Stasiun III $(1,38)$. Nilai keanekaragaman tertinggi terdapat pada Stasiun I karena kondisi sekitar sungai yang masih kurang 
dimanfaatkan oleh penduduk sekitar sungai dan juga dipengaruhi oleh faktor fisika dan faktor kimia yang sesuai dengan kondisi habitat untuk beberapa spesies makrozoobentos. Menurut Simamora (2012), makin tinggi keanekaragaman disuatu perairan maka makin rendah tingkat pencemarannya.

Tabel 2. Kelimpahan, Kekayaan dan Keanekaragaman makrozoobentos di sungai Talawaan

\begin{tabular}{|c|c|c|c|c|c|c|c|c|}
\hline Phylum & Class & Order & Family & Genus & St.l & St.2 & St. 3 & Total \\
\hline \multirow[t]{12}{*}{ Arthropoda } & \multirow[t]{12}{*}{ Insecta } & Odonata & Corduliidae & Ephiteca & 2 & 0 & 0 & 2 \\
\hline & & \multirow[t]{3}{*}{ Tricoptera } & \multirow[t]{2}{*}{ Hydropsychidae } & Hydropsyche & 11 & 0 & 0 & 11 \\
\hline & & & & Cheumatopsyche & 6 & 2 & 0 & 8 \\
\hline & & & Rhyacophilidae & Rhyacophila & 0 & 0 & 2 & 2 \\
\hline & & \multirow[t]{4}{*}{ Ephemeroptera } & Baetidae & Baetis & 15 & 9 & 34 & 58 \\
\hline & & & Lampyridae & Luciola & 16 & 9 & 0 & 25 \\
\hline & & & Caenidae & Caenis & 9 & 4 & 6 & 19 \\
\hline & & & Leptophlebiidae & Choroterpes & 0 & 1 & 1 & 2 \\
\hline & & \multirow[t]{4}{*}{ Coleoptera } & Psephenidae & Psephenus & 8 & 7 & 15 & 30 \\
\hline & & & \multirow[t]{2}{*}{ Elmidae } & Narpus & 3 & 3 & 0 & 6 \\
\hline & & & & Ancyronix & 2 & 0 & 0 & 2 \\
\hline & & & Gyrinidae & Gyrinus & 0 & 1 & 0 & 1 \\
\hline \multirow[t]{2}{*}{ Mollusca } & \multirow[t]{2}{*}{ Gastropoda } & Neotagnilosa & Melongnidae & Melanoides & 0 & 1 & 22 & 23 \\
\hline & & Mesogastropoda & Ampullariidae & Pomacea & 0 & 2 & 0 & 2 \\
\hline \multicolumn{5}{|l|}{$\mathbf{N}$} & 72 & 39 & 80 & 191 \\
\hline \multicolumn{5}{|l|}{$\mathrm{S}$} & 9 & 10 & 6 & 14 \\
\hline \multicolumn{5}{|l|}{$\mathrm{H}^{\prime}$} & 1.99 & 1.95 & 1.38 & 2.01 \\
\hline
\end{tabular}

Kelimpahan individu yang ditemukan pada Stasiun II mulai berkurang. Hal ini disebabkan karena lokasi ini merupakan daerah pemukiman penduduk sehingga sudah mulai terjadi penurunan kualitas air. Genusgenus yang tidak dapat menyesuaikan dengan perubahan lingkungan tidak dapat dijumpai pada Stasiun ini. Genus yang ditemukan pada stasiun I seperti Epitheca, Hydropsyche dan Ancyronix tidak dijumpai pada Stasiun II. Setiap genus mempunyai batas toleransi yang berbeda-beda terhadap suatu faktor yang masuk di lingkungan.

Kelimpahan individu pada Stasiun III lebih tinggi dibandingkan dengan kelimpahan individu pada Stasiun I dan II tetapi kekayaan jenis pada Stasiun ini semakin berkurang. Hal ini disebabkan karena daerah ini dimanfaatkan sebagai pemukiman penduduk sehingga aktivitas manusia seperti (limbah rumah tangga) mandi, mencuci, dan pertambangan rakyat tidak berizin yang menghasilkan limbah langsung dibuang ke sungai. Baetis merupakan genus terbanyak yang ditemukan pada Stasiun ini, disusul dengan Melanoides dan Psephenus. Pada Stasiun ini ditemukan genus Melanoides yang merupakan indikator adanya oksigen terlarut rendah dan partikel tersuspensi tinggi (Sastrawijaya, 2009).
Jenis-jenis makrozoobentos yang ditemukan pada Stasiun I sebanyak 9 Genus yaitu Epitheca, Cheumatopsyche, Baetis, Luciola, Hydropsyche, Caenis, Psephenus, Narpus dan Ancyronix. Makrozoobentos yang ditemukan di Sungai Talawaan Stasiun I termasuk dalam Order Odonata, Trichoptera, Ephemeroptera dan Coleoptera. Order Odonata yang ditemukan 1 Genus yaitu Epitheca. Order Trichoptera pada Stasiun I ditemukan 3 Genus yaitu Cheumatopsyche, Luciola, dan Hydropsyche. Pada Stasiun I (sebelum perkebunan) juga ditemukan 2 Genus dalam Order Ephemeroptera yaitu Baetis dan Caenis sedangkan dalam Order Coleoptera ditemukan 3 Genus yaitu Psephenus, Narpus dan Ancyronix. Lingkungan sekitar sungai pada Stasiun ini menunjang ketersediaan makanan dan kebutuhan oksigen sehingga organismeorganisme tersebut dapat tumbuh dan berkembang dengan baik.

Jenis-jenis makrozoobentos yang ditemukan pada Stasiun II sebanyak 10 Genus yaitu Luciola, Psephenus, Baetis, Pomacea, Melanoides, Cheumatopsyche, Choroterpes, Narpus, Gyrinus dan Caenis. Makrozoobentos yang ditemukan pada Stasiun II termasuk dalam Order Trichoptera, Coleoptera, Ephemeroptera, Mesogastropoda, 
Neotagnilosa. Order Trichoptera ditemukan 2 Genus yaitu Luciola dan Cheumatopsyche. Order Coleoptera ditemukan 3 Genus yaitu Psephenus, Narpus dan Gyrinus. Order Ephemeroptera pada Stasiun II ditemukan dengan 3 Genus yaitu Baetis, Choroterpes dan Caenis. Order Neotagnilosa pada Stasiun II ditemukan 1 Genus yaitu Melanoides. Stasiun II juga ditemukan Order Mesogastropoda dengan 1 Genus yaitu Pomacea. Order Mesogastropoda hanya ditemukan pada Stasiun II. Hal ini disebabkan lingkungan sekitar sungai yang sebagian besar merupakan perumahan penduduk yang membuang limbahnya ke sungai sehingga mengakibatkan habitat dari organisme terganggu.

Jenis-jenis makrozoobentos yang ditemukan pada Stasiun III (setelah pertambangan) sebanyak 6 Genus yaitu Psephenus, Melanoides, Caenis, Baetis, Rhyacophila dan Choroterpes. Makrozoobentos yang ditemukan pada Stasiun II termasuk dalam Order Coleoptera, Ephemeroptera, Trichoptera dan Neotagnilosa. Order Coleoptera pada Stasiun II ditemukan 1 Genus yaitu Psephenus. Order Ephemeroptera ditemukan 3 Genus yaitu Caenis, Baetis dan Choroterpes. Order Trichoptera ditemukan 1 Genus yaitu Rhyacophila. Kelimpahan Order Trichoptera dan Coleoptera menunjukan penurunan dari Stasiun I dan 2 hingga ke Stasiun III. Order Neotagnilosa ditemukan 1 Genus yaitu Melanoides. Kehadiran Melanoides pada Stasiun II dan Stasiun III merupakan indikator adanya oksigen terlarut rendah dan partikel tersuspensi tinggi (Sastrawijaya, 2009). Indeks Keseragaman yang didapatkan pada Sungai Talawaan yaitu $(0,77)$. Indeks Keseragaman tertinggi terdapat pada Stasiun I $(0,91)$, Stasiun II $(0,85)$ dan terendah pada Stasiun III $(0,77)$. Nilai keseragaman Sungai Talawaan yaitu 0,77 mendekati nilai 1 . Indeks Keseragaman Sungai Talawaan yang mendekati 1 menunjukan bahwa jumlah individu tiap jenis yang ditemukan di Sungai Talawan merata atau seragam. Indeks Keseragaman pada Sungai Talawaan tinggi menggambarkan jumlah individu seragam dan tidak ada jenis yang mendominansi.

Indeks Dominansi pada Sungai Talawaan yaitu 0,15 . Nilai ini termasuk pada kategori rendah. Hal ini menjelaskan bahwa tidak ada genus dilokasi ini yang mendominansi. Dominansi tertinggi terdapat pada Stasiun I dan 2 yaitu $(0,15)$, dan terendah pada Stasiun III $(0,13)$. Indeks dominansi Sungai Talawaan mendekati nilai 0 , artinya tidak ada jenis yang mendominansi atau dominansi rendah. Semakin kecil nilai Indeks Dominansi maka tidak ada spesies yang mendominansi sebaliknya semakin besar nilai Indeks Dominansi maka menunjukan ada spesies tertentu yang dominan terhadap spesies lainnya (Odum, 1996).

Komunitas makrozoobentos di perairan Sungai Talawaan berhubungan dengan faktor fisika-kimia di Sungai Talawaan mencakup suhu air, kecepatan arus, substrat, kecerahan, derajat keasaman $(\mathrm{pH})$, dan konsentrasi DO.

Tabel 3. Parameter Fisika dan Kimia

\begin{tabular}{|c|c|c|c|}
\hline Parameter Fisika & Stasiun I & Stasiun II & Stasiun III \\
\hline Suhu $\left({ }^{\circ} \mathrm{C}\right)$ & 29,1 & 30,4 & 30,7 \\
\hline $\begin{array}{c}\text { Kecepatan arus } \\
(\mathrm{m} / \mathrm{s})\end{array}$ & 10 & 7 & 4 \\
\hline Substrat dasar & $\begin{array}{c}\text { Berbatu, berpasir } \\
\text { dan serasah }\end{array}$ & $\begin{array}{c}\text { Berbatu, berpasir, } \\
\text { berlumut dan } \\
\text { serasah }\end{array}$ & $\begin{array}{c}\text { Berbatu dan } \\
\text { berlumut }\end{array}$ \\
\hline Kecerahan $(\mathrm{cm})$ & 25,7 & 28,3 & 29,2 \\
\hline \multicolumn{4}{|l|}{ Parameter Kimia } \\
\hline $\mathrm{pH}$ & 6 & 7 & 7 \\
\hline DO & $7,7 \mathrm{mg} / \mathrm{L}$ & $7,0 \mathrm{mg} / \mathrm{L}$ & $6,5 \mathrm{mg} / \mathrm{L}$ \\
\hline
\end{tabular}


Hasil pengukuran suhu air pada Sungai Talawaan yaitu didapatkan pada Stasiun I $(29,1)$, pada Stasiun II $(30,4)$, dan pada Stasiun III $(30,7)$. Rendahnya suhu pada Stasiun I disebabkan kondisi yang lebih ternaungi oleh tumbuh-tumbuhan. Hasil pengukuran kecepatan arus pada Sungai Talawaan, didapatkan pada Stasiun I yaitu $(10 \mathrm{~m} / \mathrm{s})$, pada Stasiun II $(7 \mathrm{~m} / \mathrm{s})$ dan pada Stasiun III yaitu (4 $\mathrm{m} / \mathrm{s}$ ). Kecepatan arus pada Stasiun I cukup deras, karena lokasi tersebut merupakan daerah sungai dengan kuat arus yang jeram dibandingkan dengan Stasiun II yang mulai melambat. Substrat pada Sungai Talawaan yaitu pada Stasiun I berbatu, berpasir dan banyak serasah, sedangkan substrat pada Stasiun II berbatu, berpasir namun sudah sedikit berlumut dan serasah. Substrat pada Stasiun III berbatu, sangat berlumut dan sedikit serasah. Hasil pengukuran kecerahan pada Stasiun I yaitu $25,7 \mathrm{~cm}$, pada Stasiun II $8,3 \mathrm{~cm}$ dan kecerahan pada Stasiun III yaitu $29,2 \mathrm{~cm}$. Pengukuran kecerahan pada Stasiun I dan II lebih rendah dibandingkan dengan kecerahan pada Stasiun III namun pengukuran kecerahan pada setiap stasiun masih bisa diukur sampai ke dasar sungai karena kurangnya bahan-bahan terlarut di dalam sungai. Tingginya kecerahan pada Stasiun III karena daerah sungai yang dangkal sehingga kecerahan masih dapat diukur ke dasar perairan. Hasil pengukuran menunjukkan $\mathrm{pH}$ pada Stasiun I sampai dengan Stasiun III adalah 6-7. Nilai $\mathrm{pH}$ terendah terdapat pada Stasiun I dan tertinggi pada Stasiun II dan 3. Tingginya nilai $\mathrm{pH}$ pada Stasiun II karena di pengaruhi oleh kegiatan domestik/pemukiman yang berada disekitar sungai. Sedangkan tingginya $\mathrm{pH}$ pada Stasiun III karena daerah ini banyak dipengaruhi oleh kegiatan pertambangan rakyat tidak berizin. $\mathrm{pH}$ dapat mempengaruhi jenis dan susunan zat dalam lingkungan perairan. Nilai DO yang diperoleh pada staiun 1 yaitu $(7,7)$, pada Stasiun II $(7,0)$ dan pada Stasiun III $(6,5)$. Nilai DO tertinggi terdapat pada Stasiun II dan Stasiun III sebesar 7,0 dan terendah pada Stasiun I sebesar 6,5. Tingginya DO pada Stasiun I disebabkan daerahnya masih kurang dimanfaatkan oleh penduduk sekitar sungai. Nilai DO terendah terdapat pada Stasiun III hal ini karena banyaknya aktivitas masyarakat setempat mulai dari mandi cuci kakus (MCK) dan tempat pembuangan limbah hasil pertambangan ilegal.

\section{KESIMPULAN}

1. Jumlah individu yang ditemukan di Sungai Talawaan, Minahasa Utara, terdiri dari 2 Phylum, 2 Class, 6 Order, 12 Family dan 14 Genus. Dari ke 6 Order yang didapat yaitu, Odonata, Trichoptera, Ephemeroptera, Coleoptera, Neotagnilosa, Mesogastropoda. Order yang paling banyak ditemukan dari ke 3 Stasiun adalah Ephemeroptera, Trichoptera dan Coleoptera. Sedangkan Order yang paling sedikit ditemukan adalah Neotagnilosa dan Mesogastropoda

2. Nilai keanekaragaman (H') pada Stasiun I (sebelum perkebunan) yaitu 1,99, Stasiun II (pemukiman) 1,95 dan Stasiun III (setelah pertambangan) yaitu 1,38 dengan nilai total ke 3 Stasiun 2,01. Nilai keanekaragaman pada Stasiun I termasuk dalam kelompok perairan yang tercemar sedang dengan Indeks $<2,0$ yaitu 1,99. Sedangkan pada Stasiun II menunjukan nilai keanekaragaman yang termasuk dalam kelompok tercemar sedang dengan Indeks < 2,0 yaitu 1,95. Pada Stasiun III nilai keanekaragaman termasuk dalam kelompok tercemar sedang $<2,0$ yaitu 1,38. Nilai total ke 3 Stasiun termasuk pada kelompok tercemar ringan dengan Indeks > 2,0 yaitu 2,01. Kualitas air Sungai Talawaan berdasarkan Indeks Keanekaragaman makrozoobentos menunjukan telah tercemar ringan sehingga air pada Sungai Talawaan sudah tidak dapat digunakan sebagai air baku air minum atau peruntukan lain yang mempersyaratkan mutu air yang sama dengan kegunaan tersebut (kelas 1).

\section{DAFTAR PUSTAKA}

Borror, D. J., C. A. Triplehorn, N. F. Johnson. 1992. Pengenalan Pelajaran Serangga. Edisi Keenam. Gadjah Mada University Press. Yogyakarta.

Fachrul, M. F. 2007. Metode Sampling Bioekologi. Bumi Angkasa, Jakarta.

Odum, E. P. 1996. Dasar-Dasar Ekologi. Edisi Ketiga. Gajah Mada University Press, Yogyakarta.

Pemak, R. W. 1953. Fresh Water Invertebrates. The Ronald Press 
Company, University of Colorado, New York.

Polii, B. dan Sonya D. N. 2002. Pendugaan Kandungan Merkuri dan Sianida di Daerah Aliran Sungai (DAS) Buyat Minahasa. Fakultas Pertanian. Universitas Samratulangi, Manado.

Sastrawijaya, 2009. Pencemaran Lingkungan. Rineka Cipta, Jakarta.

Siahaan, R. 2012. Keanekaragaman Makrozoobentos sebagai Bioindikator
Kualitas Air Sungai Cisadane, Jawa Barat-Banten. J.Bioslogos.2 (1):1-9

Simamora, D. R. 2009. Studi Keanekaragaman Makrozoobentos di Aliran Sungai Padang Kota Tebing Tinggi. [Skripsi]. Universitas Sumatra Utara, Medan.

Zulkifli H. dan Setiawan D. 2011. Struktur Komunitas Makrozoobentos di Perairan Sungai Musi Kawasan Pulokerto sebagai Instrumen Biomonitoring. Jurnal Natur Indonesia. 14 (1):1. 